Research

\title{
Words in noise audiometry in adult subjects with normal hearing
}

\author{
Widayat Alviandi, Jenny Bashiruddin, Brastho Bramantyo, Farisa Rizky \\ Department of Otorhinolaryngology Head and Neck Surgery, \\ Faculty of Medicine Universitas Indonesia/Dr. Cipto Mangunkusumo Hospital, \\ Jakarta
}

\begin{abstract}
Background: Patients with hearing disturbance will generally undergo pure tone audiometry and speech audiometry in a quiet room, but those examinations cannot evaluate the ability to understand speech in daily environment with a noisy background. Words in noise test will provide valuable information regarding patient's hearing problem in noise. Purpose: To evaluate the hearing threshold using words in noise test in adults with normal hearing. Method: This cross-sectional study was conducted in Cipto Mangunkusumo Hospital from January to April 2017. All subjects who fulfilled the inclusion and exclusion criteria underwent pure tone audiometry, speech audiometry, and words in noise test. Results: A total of 71 individuals with normal hearing were recruited for this study. Words in noise test showed the median value of $67 \mathrm{~dB}$ and $100 \mathrm{~dB}$ for Speech Recognition Threshold (SRT) 50\% and Speech Discrimination Score (SDS) $100 \%$, respectively. The SRT 50\% and SDS $100 \%$ were significantly higher in the age group 40-60 years compared to the age group 18-39 years. There was also a statistically significant difference between males and females at SRT $50 \%$ assessed by words in noise audiometry. Conclusion: Words in noise test showed a statistically significant difference in SRT 50\% and SDS 100\% between two age groups, but no difference was found between genders. The result of this study can be used as a reference for SRT and SDS values of speech audiometry test in noise.
\end{abstract}

Keywords: words in noise, speech audiometry, speech recognition threshold, speech discrimination score

\begin{abstract}
ABSTRAK
Latar belakang: Pasien dengan gangguan pendengaran umumnya menjalani pemeriksaan audiometri nada murni dan audiometri tutur di ruangan yang sunyi, tetapi pemeriksaan ini tidak dapat menggambarkan kemampuan pemahaman wicara di lingkungan sehari-hari yang ramai. Tes tutur dalam bising dapat mengevaluasi masalah pendengaran pasien dalam keadaan bising. Tujuan: Untuk mengevaluasi ambang pendengaran menggunakan tes tutur dalam bising pada orang dewasa dengan pendengaran normal. Metode: Penelitian potong lintang ini dilakukan di Rumah Sakit Cipto Mangunkusumo dari Januari hingga April 2017. Semua subjek yang memenuhi kriteria inklusi dan eksklusi menjalani pemeriksaan audiometri nada murni, audiometri tutur, dan tes tutur dalam bising. Hasil: Sebanyak 71 orang dengan pendengaran normal diikutsertakan dalam penelitian ini. Tes tutur dalam bising menunjukkan nilai median masing-masing 67 dB dan 100 dB pada Speech Recognition Threshold (SRT) 50\% dan Speech Discrimination Score (SDS) 100\%. SRT 50\% dan SDS 100\% secara signifikan lebih tinggi pada kelompok usia 40-60 tahun dibandingkan dengan kelompok usia 18-39 tahun. Hasil pemeriksaan tes tutur dalam bising menunjukkan perbedaan yang signifikan antara lakilaki dan wanita pada nilai SRT 50\%. Kesimpulan: Tes tutur dalam bising menunjukkan perbedaan yang bermakna secara statistik pada SRT 50\% dan SDS 100\% antara dua kelompok umur, tetapi tidak ada perbedaan signifikan diantara jenis kelamin. Hasil penelitian ini dapat digunakan sebagai acuan untuk nilai SRT dan SDS pada pemeriksaan audiometri tutur dalam bising.
\end{abstract}

Kata kunci: words in noise, audiometri tutur dalam bising, speech recognition threshold, speech discrimination score 
Correspondence address: Widayat Alviandi, Department of Otolaryngology, Head and Neck Surgery, Faculty of Medicine Universitas Indonesia/Dr. Cipto Mangunkusumo Hospital, Jakarta.

Email: widayat_alviandi@yahoo.com

\section{INTRODUCTION}

Hearing loss can have a high impact on speech and language impairment. It can also induce social problems and cause difficulty in communication. Difficulty in understanding speech in a noisy environment is one of the most common complaints in which adults with normal hearing may also have. Hearing in noise or public space is also associated with the cognitive process including a connection between cortical brain neuroanatomy and word processing. ${ }^{1}$

Hearing loss can be divided into two categories according to the components, i.e. audibility (loudness of voice) and distortion (hearing clarity). ${ }^{1}$ Distortion of sound causes a hearing difficulty in a crowded situation. Patients with hearing disturbance will generally undergo pure tone audiometry and speech audiometry, which was performed in a quiet room to evaluate hearing disturbance and speech understanding. Speech threshold can be assessed using speech audiometry to obtain Speech Recognition Threshold (SRT) for further evaluation of the ability to recognize speech during a communication. Meanwhile, the Speech Discrimination Score (SDS) was used to assess the ability to distinguish the speech heard. ${ }^{2}$ However, speech audiometry examination in a quiet room cannot evaluate the ability to understand speech in a daily environment. Therefore, the difficulty in understanding conversation in a crowded situation can be assessed through an examination known as speech audiometry in noise.

Speech audiometry in noise, which is also known as words in noise test, will provide useful information regarding patient's hearing problem in communication. Additionally, this can provide information about the beneficial use of hearing aids for patient's communication in a noisy environment. Words in noise test can be performed using speech signals and noise signals from different speakers. This test was developed as a tool to determine the hearing ability to understand words in a noisy background using a multitalker babble. $^{3}$

The component of hearing ability in hearing loss patients can usually be improved using an amplification system. Distortion component is a decreased ability to understand speech, especially in noisy situations. The distortion component can be evaluated using a Signal to Noise Ratio (SNR) in hearing loss patients. SNR adaptation test measures SNR with varying speech or noise intensities. Individuals with the same pure tone audiometry results can have different word understanding or discrimination abilities. The value of speech recognition can be predicted from age group, SNR level, pure tone audiometry threshold, memory, vocabulary, and lexical access time. ${ }^{4}$ Speech recognition scores in young adults are usually $25-30 \%$ better than the old age groups on the same SNR.

In Indonesia, the evaluation of hearing impairment is commonly performed using pure tone audiometry and speech audiometry. However, speech audiometry test using background noise is not yet available. The aim of this study is to evaluate the hearing threshold using words in noise test in adults with normal hearing.

\section{METHOD}

This cross-sectional study analytically described the speech threshold using background noise in adults with normal 
hearing in Cipto Mangunkusumo Hospital. Samples were taken sequentially between January and April 2017. The subjects included in this study were those who fulfilled the inclusion and exclusion criteria. The inclusion criteria were adults aged between 18 to 60 years old who speak Indonesian language with a normal hearing according to tympanometry examination, otoacoustic emission, and pure tone audiometry. The subjects were given informed consent and agreed to participate. Patients with cognitive impairment based on Mini Mental State Examination (MMSE) and Montreal Cognitive Assessment in the Indonesian version (MoCA-Ina) were excluded from this study. Samples were selected using consecutive sampling until the minimum sample was fulfilled.

All subjects went through anamnesis as well as ear, nose, and throat examination to exclude disorder in the ear, nose, and throat. Tuning fork examination was performed at frequency $128 \mathrm{~Hz}, 256 \mathrm{~Hz}, 512 \mathrm{~Hz}, 1024$ $\mathrm{Hz}$, and $2048 \mathrm{~Hz}$. All subjects in this study showed a type A during tympanometry examination and a pass result in otoacoustic emission. Then, the subjects underwent pure tone audiometry at frequency 250 to 8000 $\mathrm{Hz}$ with 0 to $100 \mathrm{~dB}$ intensity on both ears. Subjects who had a maximum score of $25 \mathrm{~dB}$ were included in this study.

The participants of this study underwent speech audiometry, followed by words in noise test. The subjects then repeated the words they heard from the recording tape. The ability to repeat $50 \%$ and $100 \%$ correct words were noted as SRT 50\% and SDS 100\%. Speech audiometry in noise was examined similar to speech audiometry using GAMA word lists with the addition of multi-talker babble with an intensity of $70 \mathrm{~dB}$ on both ears through the headphone. Speech audiometry and words in noise were noted in the speech recognition threshold (SRT) and speech discrimination score (SDS). The SRT which showed the hearing ability of a minimal
$50 \% \mathrm{~dB}$ was used to describe the speech threshold, while SDS showed the ability to repeat all the tested words. All examinations were documented and the data was analyzed using SPSS version 20, then the results were presented in text and tables.

\section{RESULTS}

A total of 71 subjects consisting of 142 ears with normal hearing were included in this study. The samples consisted of 43 female $(60.6 \%)$ and 28 male $(39.4 \%)$ subjects. The patients were divided into two groups according to their age, age group 18 to 39 years old and 40 to 60 years old with 57 (80.3\%) and 14(19.7\%) subjects, respectively. The subjects' occupations varied, ranging from doctors $(43.7 \%)$, private employees $(16.9 \%)$, civil servants and retirees $(28.2 \%)$, and other jobs (16.9\%).

The result of hearing examination using pure tone audiometry, speech audiometry, and words in noise of adult patients with normal hearing can be seen in table 1 . The mean of three frequencies consist of frequency 500 $\mathrm{Hz}, 1000 \mathrm{~Hz}$, and $2000 \mathrm{~Hz}$, was shown in Pure Tone Audiometry (PTA 3), while the mean of four frequencies similar to PTA 3 with an addition of frequency $4000 \mathrm{~Hz}$ was presented in PTA 4. The median of PTA 3 and PTA 4 were $10 \mathrm{~dB}$ for each. The result of the speech audiometry examination using a median SRT $50 \%$ value was $13 \mathrm{~dB}$, while the median of the SDS $100 \%$ was $25 \mathrm{~dB}$. Speech audiometry in noise showed the median value of $67 \mathrm{~dB}$ and $100 \mathrm{~dB}$ for SRT $50 \%$ and SDS $100 \%$, respectively.

Table 2 showed the median of three (PTA 3 ) and four (PTA 4) frequencies was $10 \mathrm{~dB}$ each. Mann Whitney test was utilized as a non-parametric test to find out the median differences between two groups in which the data were not normally distributed. There was no significant difference between right and left ear based on pure tone audiometry, 
speech audiometry, and speech in noise test. The median value of SRT $50 \%$ in speech audiometry for the right and left ears was 13 $\mathrm{dB}$ for each, while the median value of SDS $100 \%$ was $25 \mathrm{~dB}$ in each right and left ear.
During speech audiometry in noise test, the median value of SRT $50 \%$ for the right and left ear was $67 \mathrm{~dB}$ each, whereas the median value of SDS $100 \%$ was $80 \mathrm{~dB}$ in each ear.

Table 1. The result of hearing examination using pure tone audiometry, speech audiometry, and words in noise $(n=142)$

\begin{tabular}{lccccc}
\hline Variable & Mean & SD & Median & Min & Max \\
\hline PTA 3 & $10.9 \mathrm{~dB}$ & $5.1 \mathrm{~dB}$ & $10.0 \mathrm{~dB}$ & $1.7 \mathrm{~dB}$ & $25.0 \mathrm{~dB}$ \\
PTA 4 & $11.1 \mathrm{~dB}$ & $5.2 \mathrm{~dB}$ & $10.0 \mathrm{~dB}$ & $2.5 \mathrm{~dB}$ & $23.8 \mathrm{~dB}$ \\
SRT 50\% & $13.6 \mathrm{~dB}$ & $5.8 \mathrm{~dB}$ & $13.0 \mathrm{~dB}$ & $3.0 \mathrm{~dB}$ & $30.0 \mathrm{~dB}$ \\
SDS 50\% & $27.2 \mathrm{~dB}$ & $5.9 \mathrm{~dB}$ & $25.0 \mathrm{~dB}$ & $15.0 \mathrm{~dB}$ & $45.0 \mathrm{~dB}$ \\
SRT 50\% (in noise) & $67.6 \mathrm{~dB}$ & $3.0 \mathrm{~dB}$ & $67.0 \mathrm{~dB}$ & $61.0 \mathrm{~dB}$ & $76.0 \mathrm{~dB}$ \\
SDS 100\% (in noise) & $79.7 \mathrm{~dB}$ & $4.9 \mathrm{~dB}$ & $80.0 \mathrm{~dB}$ & $70.0 \mathrm{~dB}$ & $100.0 \mathrm{~dB}$ \\
\hline
\end{tabular}

Table 2. The hearing threshold of right and left ear

\begin{tabular}{|c|c|c|c|c|c|}
\hline \multirow[t]{2}{*}{ Variable } & \multicolumn{2}{|c|}{$\underline{\operatorname{Right}} \operatorname{Ear}(n=71)$} & \multicolumn{2}{|c|}{ Left ear $(n=71)$} & \multirow[t]{2}{*}{ p-value } \\
\hline & Median & Range & Median & Range & \\
\hline PTA 3 & 10.0 & $3.3-25.0$ & 10.0 & $1.7-23.3$ & 0.605 \\
\hline PTA 4 & 10.0 & $2.5-23.8$ & 10.0 & $2.5-23.8$ & 0.811 \\
\hline SRT $50 \%$ & 13.0 & $3.0-30.0$ & 13.0 & $3.0-30.0$ & 0.809 \\
\hline SDS $100 \%$ & 25.0 & $15.0-45.0$ & 25.0 & $15.0-45.0$ & 0.998 \\
\hline SRT $50 \%$ (in noise) & 67.0 & $61.0-75.0$ & 67.0 & $62.0-76.0$ & 0.811 \\
\hline SDS $100 \%$ (in noise) & 80.0 & $70.0-100.0$ & 80.0 & $70.0-90.0$ & 0.623 \\
\hline
\end{tabular}

This study also compared the median value of the hearing threshold in men and women. There was a statistically significant difference $(\mathrm{p}=0.008)$ between males and females at SRT $50 \%$ assessed by words in noise audiometry. The median of SRT $50 \%$ on words in noise audiometry in male subjects was $66 \mathrm{~dB}$, while the median in females was $67 \mathrm{~dB}$. The median value of the hearing threshold at PTA 3 and PTA 4 in males and females was not significantly different. The same thing also applied to speech audiometry, as can be seen from SRT 50\% and SDS 100\%.

Table 3. Hearing threshold difference in male and female

\begin{tabular}{|c|c|c|c|c|c|}
\hline \multirow[t]{2}{*}{ Variable } & \multicolumn{2}{|c|}{ Male $(n=56)$} & \multicolumn{2}{|c|}{ Female $(n=86)$} & \multirow[t]{2}{*}{ p- value* } \\
\hline & Median & Range & Median & Range & \\
\hline PTA 3 & 8.3 & $3.3-25.0$ & 11.7 & $1.7-23.3$ & 0.605 \\
\hline PTA 4 & 9.4 & $2.5-23.8$ & 10.6 & $3.8-23.8$ & 0.811 \\
\hline SRT $50 \%$ & 13.0 & $4.0-30.0$ & 13.0 & $3.0-30.0$ & 0.809 \\
\hline SDS $100 \%$ & 25.0 & $15.0-45.0$ & 30.0 & $15.0-45.0$ & 0.998 \\
\hline SRT $50 \%$ (in noise) & 66.0 & $61.0-73.0$ & 67.0 & $62.0-76.0$ & 0.811 \\
\hline SDS $100 \%$ (in noise) & 80.0 & $70.0-90.0$ & 80.0 & $70.0-90.0$ & 0.623 \\
\hline
\end{tabular}


The comparison of the hearing threshold according to their age group was classified into those aged $18-39$ years and $40-60$ years. A statistically significant difference was seen in all variables, such as PTA 3, PTA 4, SRT $50 \%$ and SDS $100 \%$ using speech audiometry, also SRT 50\% and SDS 100\% using words in noise between two age groups $(\mathrm{p}<0.001)$.

Table 4. Comparison of hearing threshold by age group

\begin{tabular}{|c|c|c|c|c|c|}
\hline \multirow[t]{2}{*}{ Variable } & \multicolumn{2}{|c|}{$\begin{array}{l}\text { Aged } 18-39 \text { years } \\
\qquad(n=114)\end{array}$} & \multicolumn{2}{|c|}{$\begin{array}{c}\text { Aged } 40-60 \text { years } \\
(n=28)\end{array}$} & \multirow[t]{2}{*}{ p-value* } \\
\hline & Median & Range & Median & Range & \\
\hline PTA 3 & 8.3 & $1.7-23.3$ & 16.7 & $10.0-25.0$ & $<0.001$ \\
\hline PTA 4 & 8.8 & $2.5-23.8$ & 16.0 & $10.0-23.8$ & $<0.001$ \\
\hline SRT $50 \%$ & 12.0 & $3.0-25.0$ & 20.0 & $15.0-30.0$ & $<0.001$ \\
\hline SDS $100 \%$ & 25.0 & $15.0-35.0$ & 30.0 & $15.0-40.0$ & $<0.001$ \\
\hline SRT $50 \%$ (in noise) & 66.5 & $61.0-76.0$ & 70.0 & $67.0-75.0$ & $<0.001$ \\
\hline SDS $100 \%$ (in noise) & 80.0 & $70.0-90.0$ & 85.0 & $70.0-100.0$ & $<0.001$ \\
\hline
\end{tabular}

\section{DISCUSSION}

In this study, more women had normal hearing compared to men. The tone sensitivity in men was lower than in women in accordance with the previous study. This was likely due to the noisy environment faced by men, such as at work or on the highway. ${ }^{6}$ Meanwhile, the occupation of participants in this study consisted of doctors, civil servants and retirees, private employees, and other jobs which were not exposed to noise at work.

Pure tone audiometry is generally used to evaluate the hearing threshold in which this study found that the median of hearing threshold in three (PTA3) and four (PTA4) frequencies were $10 \mathrm{~dB}$ each. This means that the median value of PTA3 and PTA4 were normal results, which is below $25 \mathrm{~dB}$. However, pure tone audiometry did not evaluate the patient's response and other neurophysiological problems. ${ }^{7}$ Therefore, an evaluation using speech audiometry was necessary.

The primary purpose of the speech audiometry test is to measure patient's ability to recognize speech stimuli and to confirm the results of the hearing threshold in a pure tone audiometry test. SRT evaluation is performed to predict the hearing loss in speech comprehension. In speech audiometry, SRT is used to assess $50 \%$ of words that can be repeated correctly by the patient, while SDS is used to assess $100 \%$ of words that can be repeated correctly. ${ }^{8}$ In this study, the difference in PTA and SRT value was $<6 \mathrm{~dB}$. A difference value of below $6 \mathrm{~dB}$ between PTA and SRT is considered as a good value, while a value between 7 to $12 \mathrm{~dB}$ shows a sufficient value, and a value above $13 \mathrm{~dB}$ indicates a bad value. In this study, there was a small difference between PTA and SRT results. The previous study by Polat et al. ${ }^{9}$ showed that there was a correlation between hearing threshold using pure tone audiometry and SRT value in speech audiometry.

In the general auditory process, sound recognition used a technique to measure the percentage of words that are correctly identified from a phonetically balanced list of words as a function of stimulus intensity. In people with normal hearing, the word recognition value increases and can reach $100 \%$ correct at around $30 \mathrm{~dB}$. The results of this study were in line with this value, where the SDS $100 \%$ value was at $27.2 \mathrm{~dB}$.

The distortion component of hearing loss was clinically reflected through the inability 
of the listener to comprehend speech in a noisy surrounding. Hearing loss distortion is also known as signal to noise hearing loss. Pure tone audiometry and speech audiometry test is often challenging to diagnose this disorder. Thus, it is necessary to perform words in noise test (speech audiometry in noise) that can provide more information about the value of the signal to noise ratio (SNR). The noise that can be used includes white noise and babble noise. Words in noise test can provide useful information about the impact of hearing loss on communication skills. This test is performed by giving a signal stimulus using words as well as a noisy signal to the listener. As a result, the SNR value of SRT $50 \%$ was obtained through words in noise test. ${ }^{3,10}$

This study used GAMA Word List, which had been previously tested and proved to have a phoneme balance. Words in noise test were also performed to evaluate the ability to understand words in a noisy or crowded environment. This study used multi-talker babble noise to simulate daily conditions, which are noisy with other people's conversations. The noise level used was $70 \mathrm{~dB}$ and the stimulus level varied starting from $70 \mathrm{~dB}$ based on the noise level which then can be adjusted to increase or decrease by $5 \mathrm{~dB}$ to obtain the value of SRT $50 \%{ }^{8}$ Wilson et al. ${ }^{11}$ performed words in noise test by using a fixed noise level of 70 $\mathrm{dB}$ and the result showed the SRT 50\% in the normal hearing was at SNR $4 \mathrm{~dB}$ SL, while the SDS $100 \%$ was at SNR $16 \mathrm{~dB}$ SL.

This study was performed in normal hearing subjects in which the SRT 50\% range in the age group 18 to 39 years was between $61 \mathrm{~dB}$ to $76 \mathrm{~dB}$, and the range of SRT $50 \%$ was from $67 \mathrm{~dB}$ to $75 \mathrm{~dB}$ for age group 40 to 60 years. The result was in accordance with the previous study, which showed clinical trials to evaluate the hearing condition and can be classified as easy at SNR $6 \mathrm{~dB} \mathrm{SL} .^{7}$ The SNR value of more than $6 \mathrm{~dB}$ SL indicates the abnormal threshold of speech audiometry in noise.

In the elderly, hearing difficulties, especially in noise in men showed a prevalence of 40 to $60 \%$ higher than in women. UK Biobank data showed that hearing difficulties in noisy environments occur around $25 \%$ in women and $35 \%$ in men. ${ }^{12}$ This is different from the results of this study, which showed that men had a better SRT 50\% value in noise than women. However, the difference was not significant. This contradictory result might be due to the number of samples dominated by women.

Aging and decrease cognitive function can affect hearing. Cognitive function plays an essential role in speech perception and pure tone sensitivity. ${ }^{13}$ The better the cognitive value, the better the SRT value. A reduction in cognitive test results can cause a decrease in SRT at approximately $0.7 \mathrm{~dB}$. Thus, the ability to compensate SRT abnormality depends on cognitive function. Cognitive evaluation using MMSE and MoCA can be beneficial as the assessments for memory disorders, attention disorders, decreased processing speed, and decreased cognitive function to be able to evaluate the ability to hear. ${ }^{6,14}$ All subjects recruited in this study had normal cognitive result based on MMSE and MoCAIna examination.

Speech audiometry in noise can identify individuals who need different interventions. In the young adult population, words in noise test can be an initial evaluation to consider the need for intervention if there is any abnormal result. ${ }^{3,10}$ The slow processing speech in old age reduces the amount of information that can be stored in a limited time. A low working memory capacity contributes to poor performance on activities that require cognitive functions such as reasoning skills. The difficulty in understanding speech indicates a problem in cognitive function. Cognitive abilities, including memory and higher functions of the brain, can decrease 
with age and can affect the communication process. Aging can also cause progressive and gradual hearing loss. People older than 40 years will be more likely to experience hearing loss due to exposure to noise. ${ }^{6,13}$

This study had several limitations. Research results varied from the small value to tremendous value and showed a fairly wide range. This might be due to the consecutive sampling technique. The subjects in this study were dominated by the young adult age group (18 to 39 years). Finding an age group of 40 to 60 years with normal cognitive function and pure tone audiometry results was not easy during data retrieval. As a result, the number of samples in the age group 40 to 60 years was not as many as the age group 18 to 39 years.

Words in noise test showed a statistically significant difference in SRT 50\% and SDS $100 \%$ between two age groups, but no difference was found between the two genders. The result of this study can be used as a reference for SRT and SDS values of speech audiometry test in noise, especially for patients with a complaint of hearing difficulty in noisy situations. Future studies should be conducted with a more proportional sample number for each gender and age group.

\section{REFERENCE}

1. Lasak JM, Allen P, McVay T, Lewis D. Hearing loss: diagnosis and management. Prim Care. 2014;41(1):19-31.

2. Glyde H, Hickson L, Cameron S, Dillon H. Problems hearing in noise in older adults: a review of spatial processing disorder. Trends Amplif. 2011;15(3):116-26.

3. Wilson RH, Watts KL. The Words-in-Noise Test (WIN), list 3: a practice list. J Am Acad Audiol. 2012;23(2):92-6.

4. Harris KC, Dubno JR, Keren NI, Ahlstrom JB, Eckert MA. Speech recognition in younger and older adults: a dependency on low-level auditory cortex. J Neurosci. 2009;29(19):6078-87.
5. Vermeire K, Knoop A, De Sloovere M, Bosch P, van den Noort M. Relationship Between Working Memory and Speech-inNoise Recognition in Young and Older Adult Listeners With Age-Appropriate Hearing. J Speech Lang Hear Res. 2019;62(9):3545-53.

6. Moore DR, Edmondson-Jones M, Dawes P, Fortnum H, McCormack A, Pierzycki $\mathrm{RH}$, et al. Relation between speech-innoise threshold, hearing loss and cognition from 40-69 years of age. PLoS One. 2014;9(9):e107720.

7. Heinrich A, Ferguson MA, Mattys SL. Effects of Cognitive Load on Pure-Tone Audiometry Thresholds in Younger and Older Adults. Ear Hear. 2019.

8. Billings CJ, Penman TM, Ellis EM, Baltzell LS, McMillan GP. Phoneme and Word Scoring in Speech-in-Noise Audiometry. Am J Audiol. 2016;25(1):75-83.

9. Polat Z, Bulut E, Atas A. Assessment of the Speech Intelligibility Performance of Post Lingual Cochlear Implant Users at Different Signal-to-Noise Ratios Using the Turkish Matrix Test. Balkan Med J. 2016;33(5):532-8.

10. Wilson RH, Trivette CP, Williams DA, Watts KL. The effects of energetic and informational masking on The Wordsin-Noise Test (WIN). J Am Acad Audiol. 2012;23(7):522-33.

11. Wilson RH, McArdle R. Speech signals used to evaluate functional status of the auditory system. J Rehabil Res Dev. 2005;42(4 Suppl 2):79-94.

12. Wells HRR, Freidin MB, Zainul Abidin FN, Payton A, Dawes P, Munro KJ, et al. GWAS Identifies 44 Independent Associated Genomic Loci for Self-Reported Adult Hearing Difficulty in UK Biobank. Am J Hum Genet. 2019;105(4):788-802.

13. Shen J, Anderson MC, Arehart KH, Souza PE. Using Cognitive Screening Tests in Audiology. Am J Audiol. 2016;25(4):319-31.

14. Panentu D, Irfan M. Uji validitas dan reabilitas butir pemeriksaan dengan Montreal Cognitive Assessment versi Indonesia (MoCA-Ina) pada insan pasca stroke fase recovery. Jurnal Fisioterapi. 2013;13:55-67. 